\title{
GENERAL INEQUALITIES VIA ISOTONIC SUBADDITIVE FUNCTIONALS
}

\author{
S. Abramovich, L-E. Persson, J. PeČArić And S. VARoŠAneC
}

Abstract. In this manuscript a number of general inequalities for isotonic subadditive functionals on a set of positive mappings are proved and applied. In particular, it is pointed out that these inequalities both unify and generalize some general forms of the Hölder, Popoviciu, Minkowski, Bellman and Power mean inequalities. Also some refinements of some of these results are proved.

Mathematics subject classification (2000): 25D15, 46B42, 46B70.

Key words and phrases: inequalities, isotonic, subadditive functional, Hölder, Popoviciu, Minkowski, Bellman, Power mean inequality, sharpening of inequalities, interpolation, K-functional, Lebesgue spaces, Orlicz spaces, Lorentz spaces, Banach function spaces.

\section{REFERENCES}

[1] S. Abramovich, J. E. PeČArić And S. VARošAnec, Sharpening Hölder's and Popoviciu's Inequalities via Functionals, Rocky Mountain J. Math., 34, (2004), 793-810.

[2] S. Abramovich, M. Klaričić BaKula, M. Matić And J. E. PeČArić, A Variant of Jensen-Steffensen's Inequality and Quasi-arithmetic Means, J. Math. Anal. Appl., 307, (2005), 370-386.

[3] C. BenNet, R. SHARPLeY, Interpolation of Operators, Acad. Press Inc., San Diego, 1988.

[4] Ju. Brudnyi, N. KRuglyaK, Interpolation Functors and Interpolation Spaces 1, North Holland, Amsterdam, 1991.

[5] L. Maligranda, Calderon-Lozanowskii Spaces and Interpolation of Operators, Semesterbericht Funktional, Tubingen, 8, (1985), 83-92.

[6] D. S. Mitrinović, J. E. PeČArić And A. M. Fink, Classical and new Inequalities in Analysis, Kluwer Acad. Publ. Dordrecht, 1993.

[7] J. E. PEČARIĆ, P. R. BEESACK, On Jessen's Inequality for Convex Functions II, J. Math. Anal. Appl., 118, (1986), 125-144.

[8] J. E. PEČARIĆ, Generalization of the Power Means and their Inequalities, J. Math. Anal. Appl., 161, (2) (1991), 395-404.

[9] J. E. Pečarić, F. Proschan and Y. L. Tong, Convex Functions, Partial Orderings and Statistical Applications, Acad. Press Inc.,San Diego, 1992.

[10] J. E. PEČARIĆ, D. VELJAn, On Maligranda's Generalization of Jensen's Inequality, J. Math. Anal. Appl., 200, (1996), 121-125. 